\title{
ANALISIS PAC (POLY ALUMINIUM CHLORIDE) DALAM MENURUNKAN KADAR COD AIR LIMBAH JASA LAUNDRY
}

\author{
Waode Rustiah $^{1)}$ Yuli Andriani Deli ${ }^{2)}$ \\ 1) Akademi Analis Kesehatan Muhammadiyah Makassar \\ ${ }^{2)}$ Jurusan Kimia, Fakultas Sains dan Teknologi, UIN Alauddin Makassar \\ Alamat Korepondensi: tia_devina@yahoo.com
}

\begin{abstract}
Abstrak
Masalah pencemaran air saat ini sudah sangat memprihatinkan, apalagi di zaman modern saat ini banyak usaha jasa cuci pakaian atau laundry yang berada disekitar rumah warga, dimana limbah jasa cuci pakaian ini merupakan derivatik zat organik. Kandungan zat organik pada air limbah jasa cuci pakaian ini mengakibatkan tingginya kadar COD air, sehingga dapat menyebabkan pencemaran bagi lingkungan dan dapat menyebabkan toksik bagi kehidupan di dalam air. Oleh karena itu perlu dilakukan solusi untuk mengatasi pencemaran tersebut, salah satu cara yang dapat dilakukan yaitu dengan proses koagulasi menggunakan koagulan Poly Aluminium Chloride. Tujuan penelitian ini untuk menentukan efektifitas Poly Aluminium Chloride dalam menurunkan kadar COD pada limbah cair jasa laundry. Penelitian ini meliputi proses koagulasi menggunakan $P A C$ dan uji penurunan kadar COD pada air limbah jasa laundry. Berdasarkan hasil penelitian dengan menggunakan variasi berat, maka dapat disimpulkan bahwa penurunan COD yang sangat baik diperoleh pada 0,3 gram yang dapat menurunkan COD sebesar 307,70 mg/L
\end{abstract}

Kata kunci : Pencemaran,PAC Poly (Aluminium Clhoride) , Koagulasi, COD.

\section{PENDAHULUAN}

Masalah pencemaran air saat ini sudah sangat memprihatinkan bagi masyarakat dan pemerintah setempat yang diakibatkan dari limbah-limbah buangan baik rumah tangga maupun industri. Apalagi di zaman modern saat ini, banyak usaha jasa cuci pakaian atau laundry yang berada di sekitar rumah warga, misalnya di kompleks BTP yang sangat luas dimana 1 blok memiliki 3 usaha pencucian pakaian, sehingga air limbah buangan jasa cuci pakaian ini diduga dapat menimbulkan permasalahan serius karena produk detergen, dimana bahan-bahan komposisinya dapat menyebabkan toksik bagi kehidupan dalam air.

Air limbah jasa cuci pakaian mengandung detergen yang merupakan suatu derivatik zat organik, dimana jenis bahan organik pada limbah jasa cuci pakaian ini dibedakan menjadi minyak (oil) dan lemak (grease). Air limbah jasa cuci pakaian juga memiliki kandungan kadar COD yang cukup tinggi 195 ppm padahal batas suatu emisi air adalah hanya 30 ppm (Trestianingrum, 2013: 3).

Kebutuhan oksigen kimia (COD) adalah banyaknya oksigen yang dibutuhkan untuk mengoksidasi bahanbahan organik secara kimia sehingga jika air limbah jasa cuci pakaian yang sudah tercemar dengan banyak kandungan organik maka kadar COD semakin tinggi dan semakin sedikit kandungan organik pada air limbah jasa cuci pakaian maka kadar COD juga semakin rendah (Trestianingrum, 2013: 2). Sehingga untuk menurunkan Kadar COD yang diakibatkan dari meningkatnya senyawa organik pada limbah cair maka penanggulangaanya sangat cocok menggunkan proses koagulasi.

Koagulasi merupakan proses yang memanfaatkan ion-ion yang mempunyai muatan berlawanan dengan muatan koloid yang terdapat dalam limbah cair sehingga meniadakan kestabilan ion. Prinsip dasar proses koagulasi adalah terjadinya gaya tarik menarik antara ionion negatif di suatu pihak dengan ion-ion positif di pihak lain. Yang bertindak sebagai ion negatif adalah partikelpartikel yang terdiri dari zat-zat organik (partikel koloid), mikoorganisme dan bakteri (Riadinati, dkk. 2014: 2). Salah satu koagulan yang dapat digunakan untuk menjernihkan air yaitu PAC sebagai koagulan sintetik. 
Poly Aluminium Clhoride (PAC) adalah merupakan jenis koagulan baru sebagai hasil riset dan pengembangan teknologi pengolahan air limbah. PAC dapat digunakan karcna koagulan ini mcmpunyai kemampuan koagulasi yang kuat, cocok digunakan untuk pengolahan limbah yang keruh dengan COD tinggi dan rentang $\mathrm{pH}$ lebar (6-9), biayanya rnurah dan mudah pengoperasiannya (Astuti, dkk. 2010:11).

Berdasarkan penelitian sebelumya Astuti (2010) tentang penurunan kadar BOD dan COD pada air lindi, kadar BOD sebelum dijernihkan sebesar 657 $\mathrm{mg} / \mathrm{l}$ dan sesudah sebesar $240 \mathrm{mg} / \mathrm{l}$ dan kadar COD sebelum penjernihan sebesar $3159 \mathrm{mg} / \mathrm{l}$ dan sesudah sebesar $485 \mathrm{mg} / \mathrm{l}$.

\section{METODE PENELITIAN}

Penelitian ini merupakan penelitian dengan pemanfaatan PAC dalam menurunkan kadar COD limbah jasa cuci pakaianyang terdiri dari atas 3 tahap penelitian, yaitu:

\section{Persiapan Sampel PAC}

Menimbang serbuk PAC masingmasing 0,$3 ; 0,4 ; 0,5$ gram untuk pengukuran COD dan memasukkan ke dalam gelas kimia $250 \mathrm{ml}$ yang berisi sampel cair limbah jasa cuci pakaian.

\section{Persiapan Sampel Cair Limbah Jasa}

\section{Cuci Pakaian}

Air limbah jasa cuci pakaian diambil di salah satu usaha cuci pakaian di Kompleks BTP, Makassar. Dimana usaha cuci pakaian ini mulai berjalan sejak tahun 2012 hingga sekarang dan limbah yang dihasilkan dibuang langsung ke dalam selokan yang kira-kira memiliki kedalaman dan luas sekitar 1 meter. Sampel air limbah diambil langsung dari pipa pembuangan menggunakan ember dan ditampung langsung pada jergen berwarna gelap.

\section{Penentuan COD dengan Metode Refluks Tertutup}

Memipet $1 \mathrm{~mL} \mathrm{~K}_{2} \mathrm{Cr}_{2} \mathrm{O} 7 \quad 0,25 \mathrm{~N}$. Menambahkan $1 \mathrm{~mL} \mathrm{Ag} 2 \mathrm{SO}_{4} / \mathrm{H}_{2} \mathrm{SO}_{4} 1 \%$ ditambahkan 0,04 gram $\mathrm{HgSO}_{4}$. Ke dalam tabung hach masukkan masing-masing 2 pada mL blanko dan $2 \mathrm{ml}$ sampel. Kemudian menutup rapat tabung hach dan homogenkan. Meletakkan tabung hach yang berisi larutan pada reaktor COD kemudian direfluks pada suhu $150^{\circ} \mathrm{C}$ selama 2 jam. Setelah itu tabung didinginkan dan larutan dimasukkan dalam erlenmeyer, ditambahkan 2 tetes indikator ferroin dan dititrasi dengan larutan Ferro Ammonium Sulfat (FAS) hingga terjadi perubahan warna yang jelas dari hijau/biru menjadi cokelat kemerahmerahan. Selanjutnya menghitung kadar COD sebelum dan sesudah perlakuan menggunakan PAC

\section{HASIL PENELITIAN}

Pada penelitian ini digunakan jenis koagulan yaitu PAC sebagai koagulan sintetik. Tujuannya untuk mengetahui seberapa besar penggunaan koagulan sintetik dalam menurunkan kadar COD. Dari hasil penelitian yang dilakukan, maka diperoleh hasil pengukuran Kadar COD Limbah Cair Jasa Laundry Menggunakan koagulan sinterik PAC. Pada pengukuran COD ini menggunakan berbagai macam variasi berat yang berbeda-beda pada PAC yaitu 0,$3 ; 0,4$; 0,$5 ; 0,6 ; 0,7$ gram, untuk mengetahui seberapa besar penurunan COD dari berbagai macam variasi waktu.

Tabel 1. Variasi berat PAC Terhadap Penurunan COD

\begin{tabular}{ccc}
\hline $\begin{array}{c}\text { PAC } \\
\text { (gram) }\end{array}$ & $\begin{array}{c}\text { Kadar } \\
\text { COD } \\
\text { (mg/L) }\end{array}$ & $\begin{array}{c}\text { Efisiensi } \\
(\mathbf{\%})\end{array}$ \\
\hline 0 & 384,63 & 0 \\
0,3 & 307,70 & 20,00 \\
0,4 & 365,39 & 5,00 \\
0,5 & 365,39 & 5,00 \\
0,6 & 350,01 & 9,00 \\
0,7 & 346,16 & 10,00 \\
\hline
\end{tabular}

\section{PEMBAHASAN}

Sampel limbah cair jasa laundry ini diambil di daerah kompleks BTP Makassar dengan mengambil limbah disalah satu usaha jasa laundry yang cukup besar dan sudah berdiri sekitar 4 tahun. Sampel limbah ini diambil langsung melalui pipa pembuangan menuju selokan, di mana limbah belum terkontaminasi dengan zat pengotor lain. Sampel diambil menggunakan jergen berwarna gelap dan disimpan pada 
ruangan gelap untuk menghindari kontak langsung dengan cahaya matahari.

Penggunaan PAC dimaksudkan untuk dapat membandingkan koagulan alami dan koagulan sintetik. Poly Aluminium Chloride (PAC) $\left(\mathrm{Al}_{2}(\mathrm{OH})_{3} \mathrm{Cl}_{3}\right)_{10}$ merupakan salah satu bahan kimia yang dapat digunakan untuk penjernihan air. Pada proses koagulasi menggunakan $\mathrm{PAC}, \mathrm{Al}^{3+}$ yang terdapat pada $\mathrm{PAC}$ akan bereaksi dengan $\mathrm{OH}^{-}$pada air limbah jasa laundry sehingga membentuk endapan. Dari hasil pengukuran, dapat diketahui bahwa kadar COD limbah cair jasa laundry sebelum perlakuan dengan menggunakan PAC yaitu 384,63 $\mathrm{mg} / \mathrm{L}$.

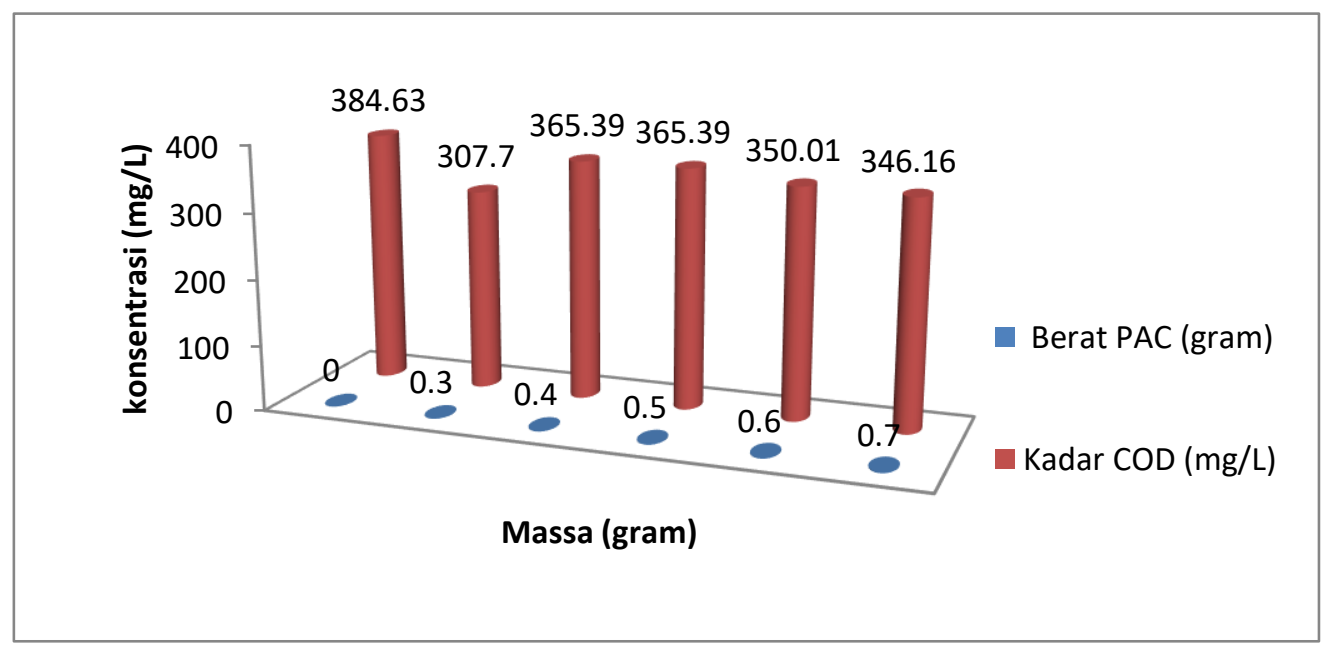

\section{Gambar1. Pengaruh Variasi Berat Koagulan PAC Terhadap Kadar COD Limbah Cair}

Pada gambar di atas, dapat dilihat efektifitas PAC dengan berbagai variasi berat dalam menurunkan kadar COD pada limbah. Pada berat yang paling rendah yaitu 0,3 gram, presentasi penurunan bernilai $20 \%$. Pada berat 0,4 dan 0,5 gram presentasi penurunan berkurang menjadi 5 $\%$. Sedangkan pada berat 0,6 dan 0,7 gram presentasi penurunan menjadi $9 \%$ dan $10 \%$. Presentasi penurunan COD menggunkan PAC sangat baik pada berat yang paling rendah yaitu 0,3 gram, hal ini menunjukkan bahwa kapasitas penyerapan sangat efektif karena PAC merupakan koagulan sintetik yang dibutuhkan untuk menurunkan kadar COD. Sedangkan untuk berat 0,$4 ; 0,5 ; 0,6$ dan 0,7 gram, presentasi penurunan menjadi berkurang karena untuk koagulan sintetik, berat koagulan yang lebih besar menyebabkan terjadinya penggumpalan koagulan sehingga menyebabkan berkurangnya luas permukaan aktif dari koagulan hingga mengakibatkan proses penyerapan jadi tidak efektif (Rahmawati, 2013:42).
Pada proses pengukuran COD ini menggunakan metode refluks tertutup, dimana prinsip pengukurannya adalah zat organik dioksidasi dengan campuran mendidih asam sulfat dan kalium dikromat yang diketahui normalitasnya dalam sebuah refluks selama 2 jam. Kelebihan kalium dikromat yang tidak direduksi, dititrasi dengan larutan ferro ammonium sulfat (FAS). Pengukuran COD juga menggunakan $\mathrm{HgSO}_{4}$ yang bertujuan untuk menghilangkan adanya gangguan dari ion klorida. Ion merkuri akan bergabung dengan ion klorida membentuk merkuri klorida. Sehingga dengan adanya ion $\mathrm{Hg}^{2+}$ ini, konsentrasi dari ion klorida menjadi sangat kecil dan tidak mengganggu oksidasi senyawa organik.

\section{KESIMPULAN}

Berdasarkan hasil penelitian, Maka dapat disimpulkan bahwa pada pengukuran kadar COD menggunakan PAC, berat yang sangat baik diperoleh pada 3,0 gram dapat menurunkan COD sebesar $307,70 \mathrm{mg} / \mathrm{L}$ 
DAFTAR PUSTAKA

Trestianingrum Ratna, $\begin{array}{r}\text { dkk.“ } \\ \text { Perbandingan }\end{array}$
Koagulan Tawas Dan Biji Kelor
Terhadap Kadar BOD Pada Air
Limbah Jasa Cuci Pakaian”.
Jurnal Pendidikan Biologi,
FKIP,Univeristas Nusantara
PGRI Kediri, 2013.

Ridaniati Ayu, dkk. " Pengaruh Kadar Air , Dosis Dan Lama Pengendapan Koagulan Serbuk Biji Kelor Sebagai Alternatif Pengolahan Limbah Cair Industri Tahu". Jurnal Teknik Kimia USU, Vol. 2, No. 1. 2013.

Ninik Lintang. " Recovery Alumina $\left(\mathrm{AL}_{2} \mathrm{O}_{3}\right)$ Dari Coal Fly ash $(\mathrm{CFH})$ Menjadi Pholyaluminium Chloryde (PAC)". Jurnal Fluida, Vol. VII, No. I. 2011.

Manurung Tambak. "Efektifitas Biji Kelor (Moringa oleifera) Pada Pengolahan Air Sumur Tercemar Limbah Domestik". Jurnal Ilmiah Fakultas Teknik LIMIT'S Vol.8 No.1. 2012.

Noviani Hardina, dkk. " Analysis Using Poly Auminium Chloride Coagulant (PAC) And Chitosan In Water Purification Proces In PDAM Tirta Pakuan Bogor." Jurnal Kimia Fakultas Matematika dan Ilmu Pengetahuan Alam. 2010.
Khasanah, Huswatun. "Efektifitas Biji Kelor (Moringa Oleifera, LAMK) Sebagai Koagulan Fosfat Dalam Limbah Cair Rumah Sakit (Studi Kasus di RSU Dr. Saiful Anwar Malang)",. Skripsi, Jurusan Kimia, Fakultas Sains dan Teknologi, Universitas Islam Negeri (UIN) Malang. 2008.

Yudo Satmoko. " Kondisi Kualitas Air Sungai Ciliwung Di Wilayah DKI Jakarta Ditijau Dari ParameteR Organik, Amoniak, Fosfat, Detergen, Bakteri Coli”. Jurnal Lingkungan, Vol. 6, No. 1, 2010.

Hidayat Saleh. "Protein Biji Kelor Sebagai Bahan Aktif Penjernihan Air". Jurnal Kimia, Vol. 2 No. 2, 2009.

Nasir Subriyer. " Pengaruh Koagulan Polyaluminium Chloride Dan Sodiumm Alginate Terhadap Kualitas Air Bersih Yang Dihasilkan Pada Pengolahan Air Sungai Dan Air Rawa Dengan Filter Keramik". Jurnal Teknik Kimia No. 4, Vol. 19, 2013.

Suwahyono, Untung. 2008. "Khasiat Ajaib Si Pohon Gaib". Yogyakarta: C.V Andi Offset.

Ahmad Rukaesih. "Kimia Lingkungan". Yogyakarta: Andi Offset. 2004 